\title{
PERKEMBANGAN TEKNOLOGI KOMUNIKASI DALAM KAITANNYA DENGAN BIDANG ADMINISTRASI PEMERINTAHAN E-KTP
}

\author{
Tasya Safiranita Ramli; Amelia Cahyadini \\ tasya_safiranita@yahoo.com; amelia.cahyadini@unpad.ac.id \\ Dosen Fakultas Hukum Universitas Padjadjaran
}

\begin{abstract}
Abstrak
Teknologi informasi dan telekomunikasi dapat dimanfaatkan pada berbagai bidang atara lain bidang pendidikan, bisnis, pemerintahan dan sosial. Perkembangan Ilmu Pengetahuan dan Teknologi (IPTEK) yang cukup pesat sekarang ini sudah menjadi realita sehari-hari bahkan merupakan tuntutan masyarakat yang tidak dapat ditawar lagi. Administrasi merupakan suatu fenomena sosial, yaitu perwujudan tertentu didalam masyarakat modern. Administrasi dalam arti sempit merupakan kegiatan ketatausahaan yang meliputi kegiatan catat- mencatat, surat menyurat, pembukuan dan pengarsipan surat sertahal-hal lainnya yang dimaksudkan untuk menyediakan informasi serta mempermudah dan memperoleh informasi kembali jika dibutuhkan. Di Indonesia, saat ini sudah mulai banyak lembaga-lembaga pemerintahan yang mulai memanfaatkan kemajuan teknologi informasi ini guna diaplikasikan sebagai media dalam memberikan kemudahan penyampaian informasi publik dan kemudahan pelayanan publik. Hal ini misalnya dalam penggunaan pendaftaran e-ktp yang dirasakan adanya kebutuhan akan penerapan teknologi informasi dan teknologi komunikasi tersebut dalam mencapai kualitas pelayanan untuk masyarakat, dan tercapainya transparansi, akuntabilitas, partisipasi, efisiensi.

Kata kunci : Teknologi Informasi, E-KTP, Pelayanan Publik
\end{abstract}

\begin{abstract}
Information and telecommunication technology is the various fields including education, business, government and social. The development of Science and Technology which is quite demands of society that can not be negotiable. Administration is a social as specific embodiment in modern society. Administration in the narrow sense is a administrative activity that includes record-keeping activities, correspondence, book keeping and mail archiving as well as other matters intended to provide information and facilitate and obtain information back. In Indonesia, there are too many government institutions that are beginning to take advantage of this information technology development to be applied as a medium in providing ease of delivering public information and the ease of public services. This is for example in the use of e-ktp registration perceived the need for the application of information technology and communication technology in achieving service quality for the community, and achieving transparency, accountability, participation, efficiency.
\end{abstract}

Keywords : Information Technology, E-KTP, Public Services. 


\section{PENDAHULUAN}

Tujuan utama perkembangan iptek adalah perubahan kehidupan masa depan manusia yang lebih baik, mudah, murah, cepat dan aman. ${ }^{1}$ Aplikasi teknologi informasi dan komunikasi dalam administrasi pemerintahan tidak lepas dari tugas pokok dan fungsi pemerintahan itu sendiri sebagai perangkat teknologi tersebut. Yang harus dilakukan oleh pemerintah yang perlu ditunjang yakni mengelola kebijakan dan mengelola pelayanan. Berbagai bentuk kebijakan, pengaturan, pembinaan, pengendalian serta pengawasan dan pertanggungjawaban dalam beragam jenis dan bidang kehidupan berbangsa atau untuk mengatasi masalah-masalah yang dihadapi bangsa memerlukan data dan informasi yang lengkap, akurat dan tepat waktu. Kegunaan dan peran teknologi informasi dan komunikasi sangat mendukung pelaksanaan tugas dan fungsi tersebut agar terselenggara secara efektif, tepat, nyaman, aman dan efisien.

Ekstensi administrasi ini berkaitan dengan organisasi. Jadi, barangsiapa hendak mengetahui adanya administrasi dalam masyarakat ia harus mencari terlebih dahulu suatu organisasi yang masih hidup, disitu terdapat administrasi. ${ }^{2}$ Undang undang Nomor 23 Tahun 2006 tentang Administasi Kependudukan dengan tujuan untuk mewujudnya tertib administrasi kependudukan dalam sekala Nasional dan menjamin kepastian hukum hak sipil penduduk, juga untuk kepentingan program program pembangunan Nasional, sehingga diperlukan pemutakhiran data kependudukan, penerbitan Nomor Induk Kependudukan (NIK) dan penerapan e-KTP. Penduduk hanya diperbolehkan memiliki 1 (satu) KTP yang tercantum nomor induk kependudukan (NIK). NIK merupakan identitas tunggal setiap 1 penduduk dan berlaku seumur hidup. ${ }^{3}$ Perangkat dari Direktorat Jendral Kependudukan dan Pencatatan Sipil Perangkat KTP Elektronik yang di distribusikan oleh Direktorat Jendral Kependudukan dan Pencatatan Sipil Kementrian Dalam Negeri melalui pihak penyedia baik berupa perangkat lunak ataupun perangkat keras. ${ }^{4}$

E KTP (Elektronik Kartu Penduduk) adalah suatu kartu tanda penduduk yang

\footnotetext{
${ }^{1}$ Tasya Safiranita, “Aspek Hukum Transaksi Perdagangan melalui Media Elektronik Dikaitkan dengan Undang-Undang Nomor 19 Tahun 2016 tentang Informasi dan Transaksi Elektronik”, http://majour.maranatha.edu/index.php/dialogia-iuridica/article/view/1757.

2 Pengertian HAN menurut Prajudi Atmosudirjo

${ }^{3}$ Pasal 13 Undang-Undang Republik Indonesia No 23 Tahun 2006 Tentang Administrasi Kependudukan.

${ }^{4}$ Peraturan Presiden No.35 Tahun 2010 Tentang Penerapan Kartu Tanda Penduduk (KTP).
} 
dibuat dari mesin elektronik dan ditulis dengan data digital. ${ }^{5}$ Pada dasarnya pelayanan verifikasi data, perekaman pas photo, tanda tangan, sidik jari dan pendataan penduduk di tempat pelayanan KTP Elektronik bergerak ( mobile ), sama dengan tahapan pelaksanaan pada pelayanan KTP Elektronik yang tetap ( stastis ) Petugas Operator mendatangi tempat yang lebih dekat dengan tempat tinggal penduduk wajib KTP. ${ }^{6}$ Dengan Undang-Undang Nomor 23 Tahun 2006 tentang Administrasi Kependudukan maka pemerintah mengeluarkan peraturan yang tertuang dalam Peraturan Pemerintah Nomor 37 Tahun 2007 tentang pelaksanaan UndangUndang Nomor 23 Tahun 2006, KTP merupakan dokumen kependudukan pribadi seseorang sebagai warga negara Indonesia.

Dengan dokumen kependudukan yang bisa dipertanggung jawabkan warga negara bisa mengurus surat-surat penting lainnya, kapan saja dan dimana saja. Sehingga Pemerintah perlu memberikan pelayanan terhadap masyarakat menyangkut dokumen kependudukan tersebut. dalam Peraturan Presiden Nomor 26 Tahun 2009 tentang Penerapan KTP Berbasis NIK Secara Nasional dan telah diubah dengan Peraturan Presiden Nomor 35 Tahun 2010 tentang Perubahan Atas Peraturan Presiden Nomor 26 Tahun 2009. Pelaksanaan KTP Elektronik membawa perubahan sistem pembuatan KTP konvensional di Indonesia yang mungkin seseorang dapat memiliki lebih dari 1 ( satu ) KTP.

\section{Metode Penelitian}

Metode Pendekatan yang dipergunakan dalam penelitian ini adalah pendekatan yuridis normatif dan yuridis komparatif. Yuridis normatif yaitu penelitian dengan menerangkan ketentuan-ketentuan dalam peraturan Perundang-undangan yang berlaku, ${ }^{7}$ yakni penelitian hukum yang dilakukan dengan cara meneliti bahan pustaka atau data sekunder sebagai bahan dasar untuk diteliti dengan cara mengadakan penelusuran tethadap peraturan perundang undangan yang berkaitan dengan permasalahan. Pengertian yuridis komparatif yaitu berdasarkan perbandingan hukum. ${ }^{8}$

\footnotetext{
${ }^{5}$ Mahmuda Pancawisma Febriharini, "Pelaksanaan Program e KTP Dalam Rangka Tertib Administrasi Kependudukan”, Serat Acitya Jurnal Ilmiah UNTAG Semarang.

${ }^{6}$ Mahmuda Pancawisma Febriharini, "Pelaksanaan Program e KTP Dalam Rangka Tertib Administrasi Kependudukan”, Serat Acitya Jurnal Ilmiah UNTAG Semarang.

7 Agus Suwandono, Deviana Yuanitasari, "Kedudukan Lembaga ALternatif Penyelesaian Sengketa Sektor Jasa Keuangan Dalam Hukum Perlindungan Konsumen”, Jurnal Bina Mulia Hukum, Volume 1 nomor 1, September 2016.

8 Soerjono Soekanto, Pengantar Penelitian Hukum, UI-Press, Jakarta, 1986, hlm. 52.
} 
Perbandingan hukum dengan negara-negara berkembang, juga untuk membandingkan instrumen hukum nasional dengan internasional dibidang perlindungan hukum terhadap perkembangan teknologi informasi dalam sistem e-ktp, yaitu ketentuanketentuan di negara berkembang lainnya.

\section{PEMBAHASAN}

Perkembangan zaman kali ini membuat beberapa sector administrasi sangat erat kaitannya dengan permasalahan administrasi, dari segi tersebut penulis dapat memberikan masukan bahwa pada saat pencanangan e-ktp dilaksanakan banyak beberapa perubahan seiring dengan perkembangan teknologi informasi. Banyaknya para pelaku administrasi yang masih gelap mata akan Administrasi Kependudukan. Dimana pada dasarnya Administrasi Kependudukan itu sendiri merupakan rangkaian kegiataan penataan dan penertiban dalam penerbitan dokumen dan data kependudukan melalui pendaftaran penduduk, pencatatan sipil, pengelolaan informasi administrasi kependudukan serta pendayagunaan hasilnya untuk pelayanan publik dan pembangunan sektor lain. ${ }^{9}$ Pelayanan E-Ktp merupakan bentuk dari Administrasi kependudukan yang pada dasarnya merupakan salah satu rangkaian penyelenggaraan pelayanan publik. Yang dimaksud dengan pelayanan publik adalah kegiatan atau rangkaian kegiatan dalam rangka pemenuhan kebutuhan pelayanan sesuai dengan peraturan perundang-undangan bagi setiap warga negara dan penduduk atas barang, jasa, dan/atau pelayanan administrasi yang disediakan oleh penyelenggara pelayanan publik. $^{10}$

Pelayanan publik adalah kegiatan atau rangkaian kegiatan dalam rangka pemenuhan kebutuhan pelayanan sesuai dengan peraturan perundang-undangan bagi setiap warga negara dan penduduk atas barang, jasa, dan/atau pelayanan administratif yang disediakan oleh penyelenggara pelayanan publik. ${ }^{11}$ Negara berkewajiban melayani setiap warga negara dan penduduk untuk memenuhi hak dan kebutuhan dasarnya dalam kerangka pelayanan publik yang merupakan amanat UUD 1945. Membangun kepercayaan masyarakat atas pelayanan publik yang dilakukan penyelenggara pelayanan publik merupakan kegiatan yang harus dilakukan seringing dengan harapan dan tuntutan seluruh warga negara dan penduduk tentang peningkatan

\footnotetext{
${ }^{9}$ Masrin, "Studi Tentang Pelayanan Pembuatan KTP Elektronik di Kantor Kecamata Samarinda ULU Kota Samarinda”, eJournal Pemerintahan Integratif, 2013, 1 (1): 68-81.

${ }^{10}$ Undang-Undang Nomor 25 Tahun 2009 Tentang Pelayanan Publik.

${ }^{11}$ Pasal 1 angka 1 Undang-Undang Nomor 25 Tahun 2009 tentang Pelayanan Publik.
} 
pelayanan publik. Pelayanan publik yang dilakukan oleh penyelenggara negara dapat harus dilakukan secara adil dan merata, serta mampu mengikuti perkembangan teknologi.

Fungsi E-Ktp meliputi: ${ }^{12}$ 1) Sebagai identitas jati diri; 2) Berlaku Nasional, sehingga tidak perlu lagi membuat KTP lokal untuk pengurusan izin, pembukaan rekening Bank, dan sebagainya; 3) Mencegah KTP ganda dan pemalsuan KTP; Terciptanya keakuratan data penduduk untuk mendukung program pembangunan. Pada dasarnya pembuatan E-Ktp adalah untuk mempermudah pemerintah dalam membuat suatu database yang berisi mengenai data kependudukan secara penuh, utuh dan akurat terhadap segala data mengenai masyarakat itu sendiri. Hal tersebut dimaksudkan agar pemerintah dapat bertindak secara cepat dan tepat ketika terjadi suatu permasalahan terkait kejahatan maupun terkait masalah-masalah yang terjadi dalam kependudukan itu sendiri.

Namun yang menjadi masalah adalah justru bukan masalah dalam system, namun terkait dengan sumber daya yang menjalankan sistem tersebut, yaitu manusia itu sendiri. Kualitas manusia menjadi tolok ukur apakah program pengumpulan database itu sendiri dapat terlaksana dengan baik atau tidak. Hal tersebut Dalam kenyataan saat ini, justru banyak pihak yang "berkepentingan" justru melakukan perbuatan yang tidak semestinya.

Dalam hal ini beberapa pengertian yang dapat disimpulkan yaitu informasi merupakan data mentah atau fakta - fakta yang telah diolah sehingga memiliki suatu arti dan nilai bagi penerimanya.Adapun nilai - nilai yang terkandung dalam informasi tersebut dapat dilihat dari beberapa dimensi yaitu informasi tersebut relevan, akurat, tepat waktu, dan lengkap. Adapun istem informasi adalah kombinasi teratur apapun dari orang - orang, hardware, software, jaringan komunikasi, dan sumber daya yang mengumpulkan, mengubah, dan menyebarkan informasi dalam sebuah organisasi. Dari definisi - definisi di atas, dapat disimpulkan bahwa sistem informasi adalah sekumpulan komponen yang saling terkait, yang mengumpulkan, memproses, menyimpan, dan menyediakan informasi dalam sebuah organisasi untuk membantu dalam penyelesaian tugas bisnis dan pengambilan keputusan.

\footnotetext{
${ }^{12}$ http://www.e-ktp.com/fungsi-e-ktp/ diakses pada tanggal 30 Oktober 2017 pukul 22.47 wib.
} 
Penerapan e-KTP diklaim gagal dan penuh dengan indikasi kecurangan (korupsi) karena banyaknya kejanggalan pada produk yang telah di hasilkan. Tujuan untuk mempermudah proses registrasi dan administrasi penduduk tidak dapat diwujudkan pemerintah dengan program e-KTP. Database yang tidak terintegrasi secara nasional dan system aplikasi perekam e-KTP yang tidak jelas menjadi factor yang menyebabkan program e-KTP diaggap gagal.

\section{PENUTUP}

Dalam rangka mengembangkan sistem administrasi yang baik, beberapa program pemerintah yang kali ini sudah terkait dengan kemajuan perkembangan dsistem teknologi informasi banyak sekali perubahannya, namun hanya beberapa program saja yang dapat berjalan dengan sempurna. Dari pantauan penulis pada saat melakukan tinajauan dalam sistem e ktp masih banyaknya penerapan e ktp yang diklaim penuh dengan sisi negative baik itu dalam segi korupsi atau banyak sekali kejanggalan produk yang dihasilkan. Dari kesimpulan yang kami peroleh awal mula pembentukan sistem ini memounyai tujuan yang baik untuk memudahkan sistem dan proses registrasi tetapi disayangkan proses - proses tersebut masih banyak yang tidak dapat diwujudkan dikarenakan sistem database yang belum terintegrasi secara memadai sehingga banyak masyarakat yang menilai bahwa program pemerintah kali ini masih banyak yang harus diperbaiki agar menghasilkan proses yang sesuai dengan semestinya.

\section{DAFTAR PUSTAKA}

\section{Buku:}

Soerjono Soekanto, Pengantar Penelitian Hukum, UI-Press, Jakarta, 1986.

\section{Jurnal :}

Agus Suwandono, Deviana Yuanitasari, "Kedudukan Lembaga ALternatif Penyelesaian Sengketa Sektor Jasa Keuangan Dalam Hukum Perlindungan Konsumen”, Jurnal Bina Mulia Hukum, Volume 1 nomor 1, September 2016.

Tasya Safiranita, “Aspek Hukum Transaksi Perdagangan melalui Media Elektronik Dikaitkan dengan Undang-Undang Nomor 19 Tahun 2016 tentang Informasi 
dan Transaksi Elektronik", http://majour.maranatha.edu/index.php/dialogiaiuridica/article/view/1757

Mahmuda Pancawisma Febriharini, "Pelaksanaan Program e KTP Dalam Rangka Tertib Administrasi Kependudukan", Serat Acitya - Jurnal Ilmiah UNTAG Semarang.

Masrin, "Studi Tentang Pelayanan Pembuatan KTP Elektronik di Kantor Kecamata Samarinda ULU Kota Samarinda”, eJournal Pemerintahan Integratif, 2013, 1 (1): $68-81$.

\section{Peraturan Perundang-Undangan :}

Undang-Undang Republik Indonesia No 23 Tahun 2006 Tentang Administrasi Kependudukan.

Undang - undang Nomor 25 Tahun 2009 Tentang Pelayanan Publik.

Peraturan Presiden No.35 Tahun 2010 Tentang Penerapan Kartu Tanda Penduduk (KTP). 